Issues in Business Management and Economics Vol.8 (3), pp. 33-47 September, 2020

Available online at https://www.journalissues.org/IBME/

https://doi.org/10.15739/IBME.20.004

Copyright (C) 2020 Author(s) retain the copyright of this article

ISSN 2350-157X

CrossMark

\&click for updates

Original Research Article

\title{
Impact of global economic recession on basic physiological needs of Nigerian citizens
}

\section{Ugwuanyi Georgina Obinne, \\ 2*Okanya Ogochukwu \\ Chinelo \\ and \\ ${ }^{3}$ Efanga Udeme Okon}

${ }^{1}$ Department of Banking and

Finance, College of Management

Sciences, Michael Okpara

University of Agriculture,

Umudike, Abia State,

${ }^{2}$ Department of Banking and

Finance, Institute of Management

and Technology Enugu,

${ }^{3}$ Department of Banking and

Finance, Faculty of Management

Sciences, University of Calabar, Calabar,

${ }^{*}$ Corresponding Author

Email: ookanya@imt.edu.ng
This study evaluates how the most basic of human needs are impacted by economic recessions and downturns. Specifically we focus on Nigerians given that results from this study can be generalized for much of Sub Saharan Africa given the similarities between Nigeria and others within this region. The research was qualitative and quantitative in design and data used were from both primary and secondary sources. The Primary data was sourced through questionnaires distributed to 432 respondents while secondary data was garnered from published articles and reports on the subject. Means and standard deviation were statistical tools employed to address research questions 1, 2 and 3; while the T-test technique was then used to analyze the 1,2 and 3 hypotheses. For the quantitative aspect (against $4^{\text {th }}$ research question), having found that the unit root test on the time series data displayed a combination of $1(0)$ and $1(1)$ variables, the Autoregressive Distributed Lag (ARDL) Model (Bounds Test inclusive) was employed for data estimation. Among other things, this study highlighted the plight of Nigeria's middle and lower income groups following economic upheavals. Findings reveal that economic downturns as seen within the study period made it markedly more difficult for average Nigerians in both the urban and rural areas to feed and meet the most basic needs. The difficulties faced by individuals were further confirmed by a reduced expenditure on health and the acquisition of household assets were seen to drop markedly. Key markers of economic recession such as interest rate, public debt and real exchange rate were found to be significant both in the short and long-run. The research concludes that the negative effect of economic recession on the health of Nigerians remained significant throughout the study period.

Keywords: Economic recession, physiological needs, Nigerians, health.

\section{INTRODUCTION}

This research is a follow up study to an earlier research by Ugwuanyi and Obiekwe (2017) titled "Impact of Economic Recession Induced Problems on Nigerian Economic Growth". This earlier research provided evidence of the relationship and effects of the studied variables on Nigerian economic growth. The direct effect of those variables on
Nigeria's economic growth suggests a corresponding impact on the physiological needs either directly or indirectly. This study is thus an attempt to provide much needed insight on the relationship (if any exists) between economic downturns and the basic physiological needs of individuals. 
Physiological needs are the most basic of requirements for a human to survive. The needs for oxygen, food, sleep and reproduction are ranked as being the basis, the foundation for living. If these needs are unmet, the human body ceases proper functioning and will ultimately fail. It is only after physiological needs have been met that individuals can consider pursuing other needs such as health and safety. Kelly (2014) labels physiological and safety needs as "Deficiency Needs" in his analysis of Maslow's original five stage model. Kelly extends Maslow's theory to an eightstage model of hierarchy of needs pyramids.

Globally there have been several episodes of economic and financial crises which all have the effect of massive destabilization. Starting from the Great Depression of the 1930s to that of 2008 and even the current Covid 19 crises, there appears to be a common thread showing that no sphere is immune from the overarching domino effect of a recession. The drops in demand are almost immediately followed by production cuts. Corporations unable to survive get shut down and bankruptcies become the new normal. The eventual outcome is unemployment and the resulting shocks get transmitted far and wide. For the more advanced nations, the existence of several safety nets like unemployment payments and business protection plans to an extent reduce the citizens from suffering the full effect of the crises being experienced. For a developing nation like Nigeria, the near absence of well functioning social protection means that the absence or even delay of income spells disaster. And so at the micro level of households the crises is immediately transmitted and its impact felt as breadwinners having lost their jobs are unable to provide even the most basic of needs. For those still employed, salary payments become irregular and so feeding and the ability to pay house rents get challenged.

It is thus the focus of this study to firstly identify exactly how a recession affects an individual's ability to meet these basic needs. Next is to determine the nature of relationship that exists and then ascertain just how significant such an effect may be.

To be sure, for the Nigerian citizens that survive recessions and economic downturns, it is not without an effect on day to day functioning activities, needs and the ways they live their lives - their standards of living. This is then the essence of this study - to find out the impact of the economic recession on the basic physiological needs of Nigerian citizens.

When there are deficiencies in the provision of physiological needs, it will definitely affect the provision (by both government and individuals) for the citizens. This research therefore needs to answer the following research questions: How does an economic recession affect the regularity of the citizens' feeding habits in Nigeria? To what extent does economic recession affect the provision of shelter in Nigeria? To what extent does an economic recession influence the pattern to which the citizens take care of their health needs? What is the impact of economic downturn/ recession on Health care needs expenditure of Nigerians?
This research is presented in five sections.

This study spans thirty two years starting 1985 through 2017.

\section{Objectives of the Research}

The main objective of this research is to determine the impact of the global economic recession on the physiological needs of Nigerian citizens. The specific objectives are to:

- Ascertain how the global economic recession affects feeding regularity of Nigerians in both rural and urban areas.

- Determine the extent to which economic downturns affects the provision of shelter for households across Nigeria in both rural and urban areas.

- Investigate the extent to which the global economic recession influences the health seeking capabilities of Nigerian households.

- Examine the impact of economic recession on the health care expenditure of Nigerian households

\section{Hypotheses}

$\mathrm{H}_{1}$ : Economic recession-induced problems do not differ significantly between urban and rural areas on the impact on the regularity of feeding habit in Nigeria.

$\mathrm{HO}_{2}$ : Economic downturns do not have any significant effect on the provision of shelter for households in both rural and urban areas of Nigeria.

$\mathrm{HO}_{3}$ : The effect of economic recession induced problems on the health seeking behavior of individuals does not differ significantly between urban and rural areas.

$\mathrm{HO}_{4}$ : Economic recession has no significant impact on the health care expenditure of Nigerian households.

\section{Literature Review}

\section{Conceptual Framework}

A global recession is one that affects several countries simultaneously. It is characterized by declining output and a 'slowing down' of the economy. The general malaise becomes a vicious circle as dwindling output causes employment cuts which then result in further drops in aggregate expenditure. An economic recession is typically defined as a significant decline in economic activity, real GDP, real income, employment, industrial production and sales following a decline in the aggregate demand for at least two consecutive quarters (myacountry course.com, 2017).

In the event of a global economic recession, the economic, political, technological, and cultural linkages that connect individuals, communities, businesses, governments and countries around the world are the primary causes of contagion and the more connected an economy is to an affected economy, the greater its exposure and hence the greater the relative impact. In the aftermath of the 
2008/2009 economic crises, the Nigerian economy, recognized as one of Africa's most dynamic economies suffered crippling effects of the economic downturn and the crises resulted in breakdown and a marked decline in economic vigor .Recessions typically affect employment and even the management of human resources in organizations. Decision on wages, overtime, and hiring or laying off workers all hinge on general economic conditions.

The retrenchment and downsizing would most likely be a direct route through which workers get affected following a recession. Rising unemployment, declining consumer confidence and reductions in aggregate demand and supply exacerbate the problem and the effects of recession get further ingrained and the ability to satisfy even the most basic of physiologic needs gets impinged. This research is premised on the need to understand the dynamics of a global economic recession and examine the issues involved.

\section{Government Expenditure on Health}

Total health expenditure is the sum of public and private expenditure on health services whether for preventive and/or curative purposes, family planning activities, nutrition activities and any emergency aid designated for health. The provision of water and sanitation are typically not included as health expenditure costs. Total health expenditure is a fraction of Gross Domestic Product GDP and a cursory look through Nigerian health expenditure over the years shows health expenditure amounted to a mere 3.6\% of GDP in 2015. Indeed the period 2001 through 2015 was characterized by fluctuations (World Data Atlas, 2015). Only $8 \%$ of government expenditure was on health and possibly explains why Nigeria ranked 141st on government expenditure on health (World Data Atlas, 2015).

\section{Theoretical Review}

To explain the link between economic recessions and the attainment of basic physiological needs, this research effort adopts three theories.

\section{Keynesian Economic Theory on Recession}

Keynes (1936) first presented his now famous fiscal theories which formed the basis of several other Keynesian theories following the Great Depression. Keynes proposed different theories of how in the short run, and especially during recession, economic output is strongly influenced by aggregate demand (total spending in the economy). Keynes thus opined that a possible solution out of a recession was for increased government spending. In Keynes view, increased expenditure on infrastructure would stimulate the economy given that economic activity would drive aggregate demand. Understandably aggregate demand is at its lowest in a recession because of the associated unemployment that characterizes a recessionary period.

\section{Abraham Maslow's Hierarchy of Needs Theory:}

Maslow's hierarchy of needs was propounded in 1943. The theory presents human needs in a structured pyramid shaped five tier models. At the base of the pyramid are the basic physiological needs and the apex is capped by an individual's need for self actualization. The theory was premised on several assumptions with the second stating that rational humans would always choose to satisfy the primary physiological needs before the secondary more complex needs. Maslow thus suggests that the basic physiological needs: food, shelter, water, air, etc must be met before any attempt is made to attain any other achievement.

\section{Hangover Theory}

Krugmen's Hangover theory proposed in 1998 draws from the boom and burst episodes seen in economies and suggests that slumps and downturns are the price we pay for the boom we enjoy. This means that the boom and burst episodes are linked and it is one that gives birth to the other. In Krugmen's view, a recession is the necessary punishment for the excesses of a preceding boom period during which the economy expanded and the Boom that follows a recession is the consolation of having endured a recession. After comparing this theory to some other extant theories such as that of Keynes and a few others, opinion remains divided and whatever support it enjoys is equally matched by widespread criticism. While agreeing that recessions are inevitable, critics of the theory agree that "it is ideas, not vested interests that are dangerous for good or evil (www.pkarchive.org)

\section{Empirical Review}

\section{Impact of Economic Recession on Economic Growth and Physiological needs of Citizens}

Massavrat and Sha (2015) assessed the impact of recession on Consumer behavior in Dubai. Their aim was to understand the impact of global recession on consumer shopping behavior and how consumer consumption and saving pattern changed across different product categories during and after recession. A total of 235 respondents were issued structured questionnaires. Paired sample t-test and ANOVA were employed to analyze the data. The research findings provide empirical evidence that the priorities of the consumers significantly changed following a recession.

Gautan, Singh and Sharma's 2014 research studied the effect of a global recession on the Indian telecommunications industry. Specifically the study sought to analyze whether the flows of foreign Direct Investments to the telecom sector had faltered during or after the global crisis. Their findings suggest that even with the prevailing recession, India's economy witnessed a steady growth in the FDI inflows to the Telecom sector.

The possible positive linkage between global financial 
crises, recession and poverty in developing nations are highlighted by Bauer (2009). Agreeing, Oyesiku (2009) identifies factors such as economic crisis occasioned by inflation, loss of consumer confidence, excess supply over demand, and excess demand over supply as triggers that could initiate an economic recession.

In Nigeria's case, Ugwuanyi and Obiekwe (2017) provide evidence that the global economic recession not only affected the attainment of basic physiological needs but jeopardized mental health as seen by the marked increases in mental health disorders following the recession. This confirms findings of Muanya (2016) who noted the increases in documented suicides, violent crimes, depression, and alcohol dependency among other vices. Muanya attributes the increased negatives to the economic recession as he observes a peak in the years closest to the recession. Sadly the statistics suggest that 6.5 of every 100,000 committed suicide in Nigeria with males accounting for most of the suicides (WHO statistics, 2012; Muanya, 2016). The increasing suicides in Nigeria are confirmed by Opejobi (2017) who reports a 2017 incident where a medical doctor, Allwel Orji jumped into the Lagos lagoon on March 21. The reason cited for the suicide was government's decision to place doctors on either half pay, irregular pay or no pay at all for some. The victim was pained by the hardship persons with dependants would face.

The positive link between economic recession and mental health disorders is further confirmed by Ugwuanyi and Obiekwe (2017) citing Olugbile (2017). Chinguwo and Blewit (2012) posited that economic recession, financial crisis and climate change problems combined to make life even more difficult for many working people and their families. Indeed economic recession stagnates wage growth and increases the proportion of people on low pay, as well as swelling unemployment and underemployment (Mailafia, 2016).

Cheung and Marriot (2015) studied the impact of an economic downturn on addiction and mental health service utilization. Specifically they sought to determine the utilization rate of addiction and mental health services during and following economic downturn in Alberta. The researchers hypothesized that increased unemployment results in increased addiction and mental health service utilization. This assumption is premised on the belief that unemployed persons face increased stress and definitely would seek professional support. The methodology employed for their study involved two basic searches to identify relevant literature. First search used Medline and PsychINFO databases while second search of academic and grey sources of literature used the PsychINFO database, Google and Google scholar. They received over 120 articles and emerged with 12 articles published within 2000 to 2015 originating from either the United States or Europe. Articles covered major economic turndowns of the early 1980s, 1990s, and 2008-09 focusing primarily on 2008-09 down turn. Their research findings reveal that utilization rates of medical, dental and mental health services declined in during periods of economic downturn (Burgard and Hawkins, 2014). Specifically, literature revealed an overall reduction in physician visits by about $7-8 \%$ for females and $25 \%$ for males. The reduction, as suggested may be due to the lack of health insurance coverage; and also gender differences may be attributed to males having less coverage than females (Chen and Dagher, 2014).

Frasquilho et al. (2016) equally examined the possible association between economic recession and mental health outcomes. The methodology employed involved a review of records identified through Medline PsyINFO, SciELO, and EBSCO host accepting only original research papers published and peer - reviewed between 2004 and 2014 and considered only reports about economic factors and proxies of mental health. Most of the research was based on cross- sectional studies which seriously limited causality inferences. Findings revealed that one - hundred - and-one papers met their target and consistently showed that economic recessions and their indicators (such as unemployment, income decline, and unmanageable debts) are significantly associated with poor mental well being, increased rates of common mental disorders, substance related disorders, and suicidal behaviors. The study concluded by showing that economic recession is possibly associated with a higher prevalence of mental health problems, including common mental disorders, substance disorders, and ultimately suicidal behavior.

JCDA (2009) conducted a research captioned "Notable Numbers - Economic Recession and Health Care Spending". The study based on Household spending on health care as a proportion of overall household spending spanning from 2003-2007. The research question was "will the worsening economic conditions have any consequences on private health care services, in general, and dental care in particular"? They methodically approached their study of Canadian household spending on health care services province by province. This included all expenditures such as personal and property taxes, food, housing costs and transportation. Findings reveal that as unemployment rate (a key economic indicator) rises and Canadians lose health insurance coverage, a direct potential consequence is reduced visits to the dentist and health facility. They concluded that since economic conditions affect provinces differently potential changes in private health care spending will also vary from province to province.

\section{METHODOLOGY}

\section{Research Design}

This research was both qualitative and quantitative; and for the quantitative we adopted an ex-post-facto research design. Independent variables served as indicators of economic recession.

\section{Population and Sample Size}

In our methodology, we are guided by Afolabi (2019) 
Table 1. Mean Responses and Standard Deviations of the Respondents on how an Economic Recession affects the Regularity of Citizen's Feeding Habits across Rural and Urban Nigeria

\begin{tabular}{|c|c|c|c|c|}
\hline \multirow[t]{2}{*}{ S/No } & \multirow{2}{*}{$\begin{array}{l}\text { Item Statement: Extent Economic Recession-Induced } \\
\text { Problems have affected the regularity of feeding. } \\
\text { Economic Recession-Induced Problems: }\end{array}$} & $\begin{array}{l}\text { Urban } \\
\text { No } 213\end{array}$ & $\begin{array}{c}\text { Rural } \\
\text { No219 }\end{array}$ & $\begin{array}{c}\text { Total } \\
\text { No } 432\end{array}$ \\
\hline & & X SD Dec & X SD Dec & X SD Dec \\
\hline 1 & $\begin{array}{l}\text { Make things difficult for the average citizens to have } \\
\text { three square meals per day. }\end{array}$ & $3.49 .68 \mathrm{HE}$ & 3.73.45VHE & $3.54 .65 \mathrm{VHE}$ \\
\hline 2 & $\begin{array}{l}\text { Make it difficult for the average citizens to eat balanced } \\
\text { diet meals }\end{array}$ & $3.35 .73 \mathrm{HE}$ & $3.41 .62 \mathrm{HE}$ & $.71 \mathrm{HE}$ \\
\hline 3 & $\begin{array}{l}\text { Have reduced an average citizen's market access to } \\
\text { available resources }\end{array}$ & $3.33 \quad .91 \mathrm{HE}$ & $.55 \mathrm{HE}$ & 3.36.78 $\mathrm{HE}$ \\
\hline 4 & $\begin{array}{l}\text { Have reduced an average citizen's access to available } \\
\text { resources }\end{array}$ & $3.49 .68 \mathrm{HE}$ & 3.73.45VHE & 3.54.65VHE \\
\hline 5 & $\begin{array}{l}\text { Have reduced capacity of average citizens to farm } \\
\text { products. }\end{array}$ & $3.35 .73 \mathrm{HE}$ & $3.41 .62 \mathrm{HE}$ & $3.36 \quad .71 \mathrm{HE}$ \\
\hline & $\begin{array}{l}\text { Cluster Means. } \\
\text { Mean difference between urban and rural areas }\end{array}$ & 3.40.45 HE & $\begin{array}{l}3.56 .54 \mathrm{VHE} \\
.16\end{array}$ & 3.43 .70 \\
\hline
\end{tabular}

Source: Field work data, 2020

Key: VHE means Very High Extent; HE means High Extent; LE means Low Extent while VLE means Very Low Extent

whose study of decision making in women's organization involved similar methods. Primary data from questionnaires and oral interviews administered on the 432 respondents chosen across the six geo-political zones of Nigeria yielded a treasure trove of findings. Our sample was drawn through multistage sampling techniques from 4320 women across 2160 women organizations existing in six randomly selected states namely Enugu (South East), Uyo (South South), Benue (North Central), Ondo (South West), Katsina (North West) and Taraba (North East). Our decision to adopt a $10 \%$ sample is guided by Ali (2006), who propounded among others that for populations that run in thousands that $10 \%$ of it can stand as its sample size.

\section{Analytical Techniques:}

Both the Mean and standard deviation were used to address the research questions 1,2 , and 3 , while the T-Test was adopted as the appropriate analytical instruments for analyzing formulated hypotheses !,2 and 3.

\section{Sources of Data}

Data were obtained from both primary and secondary sources. The secondary data for ascertaining impact of economic recession were sourced mainly from: Central Bank of Nigeria's published statistical Bulletin of various issues; data for real exchange rate were sourced from World Bank Development Indicators and aggregate poverty rate were sourced from world data atlas and Nigeria's Bureau for statistics quarterly reports of various issues, while the primary data were obtained using questionnaire as instrument of data collection.

However, the data regressed are annualized time series data and covers the years 1985-2017. The choice of the year 1985 is to cover the first full year recession in Nigeria.

The questionnaire was pre-tested and amended before administration.

Following laid down institutional guidelines and best practices, it was agreed that there was no need to secure ethical approval for this study. Oral informed consent was obtained from all participants and participants were duly informed that participation was not compulsory and so withdrawal at any time was an option to be exercised.

\section{RESULTS PRESENTATION AND DISCUSSION}

\section{Research Question One}

How does an economic recession affect the regularity of the citizens' feeding habits across rural and urban Nigeria?

Data from Table 1 above presents the mean ratings and standard deviations of urban and rural women on how global economic recession has affected the regularity of feeding in urban and rural areas in Nigeria. Findings indicate that women from rural areas maintained that economic recessions made it difficult for the average citizens to have three square meals per day while also reducing the an average citizen's access to available resources to a very high extent. On the other hand, women from urban areas agreed that economic recession-induced problems caused difficulties and made it harder for average citizens to have three square meals per day. Also average citizens' access to available resources reduced to a high extent but did not qualify to be ranked on a higher scale as indicated by items 1 and 4 . Women from both urban and rural areas agreed that economic recession-induced problems generally rendered eating balanced diet meals more difficult; also recession was found to generally reduce market access of average citizens' to available resources. Again the capacity of average citizens to access farm 
Table 2. Results of t-test Analysis for Equality of Means of Respondents on Extent Economic Recession-Induced Problems have affected the Regularity of Feeding Habit in Nigeria

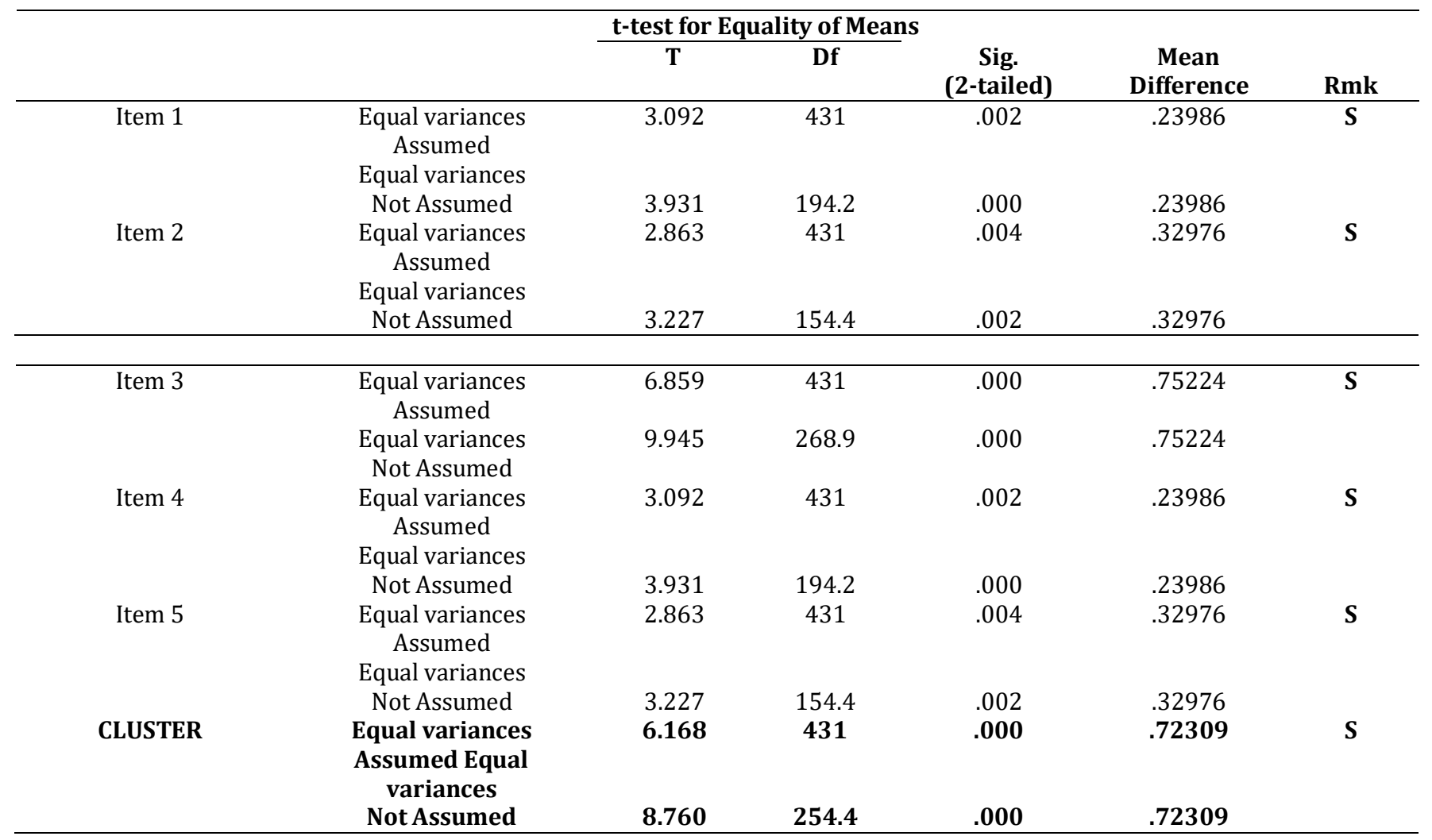

Source: Field work data, 2020

products was reduced to a high extent as shown by items 2 , 3 and 5 respectively. The cluster means confirms that the effect of recessions on feeding habits has been severe but has differed $n$ depth whereas the rural women state that the effect has been to a very high extent, urban respondents suggest that the effect has been to a high extent. From the oral interviews we deduce that the slightly better plight of the urban women may be related to the presence of more options than are readily available in the rural areas. The standard deviation of each item from the mean ranged from $0.45-0.91$ indicating that the respondents were not too far from the mean and did not deviate significantly from one another in their responses. This therefore further validates the mean.

A corresponding hypothesis formulated to address the research question is:

\section{Hypothesis One:}

Economic recession-induced problems do not differ significantly between urban and rural areas on the impact on the regularity of feeding habit in Nigeria.

The results presented in Table 2 above indicate that economic recession-induced problems differ significantly between urban and rural areas on how the regularity of feeding is impacted. The overall calculated $t$-value of 6.168 has a probability value of .000 and is therefore significant at .05 level. The calculated t-values of 3.092, 2.863, 6.859, 3.092 and 2.863 in respect of items 1, 2, 3, 4 and 5 have probability values of $.002,004, .000, .002$ and 004 and are therefore significant at .05 level of significance. Since the calculated $t$-values of the five items have probability values of less than .05, the null hypothesis of no significant difference in the impact of economic recession-induced problems between urban and rural areas on the regularity of feeding habit in Nigeria is rejected. Consequently, economic recession-induced problems have been found to have greater impact on the rural than on urban areas as it relates to the regarding the regularity of feeding habits.

\section{Research Question Two:}

How has the global economic recession affected the capacity of citizens in the provision of shelter for family members across urban and rural areas in Nigeria?

From data presented in Table 3 above, we find the mean ratings and standard deviations of respondents on the extent economic recession-induced problems have affected the capacity of the citizens in the provision of shelter for family members in both urban and rural areas in Nigeria. The results indicate that both classes of respondents 
Table 3. Means and Standard Deviations of Respondents' Responses on Extent Economic Recession-Induced Problems affected the Capacity of the Citizens in Provision of Shelter for Family Members across Urban and Rural Areas of Nigeria

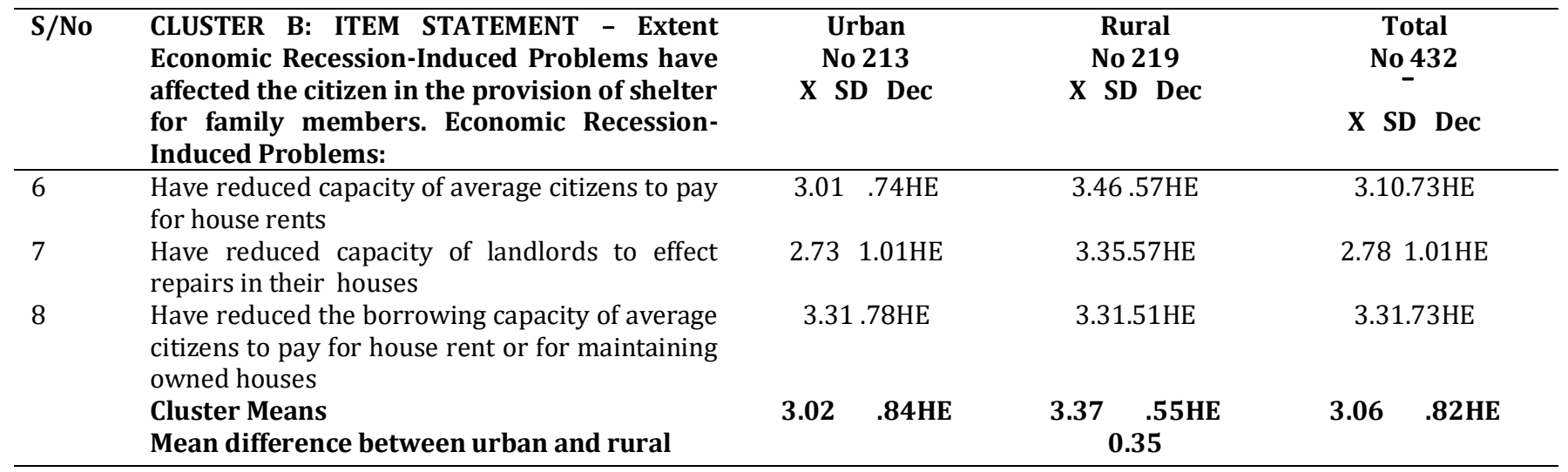

Source: Field work data, 2020

Key: VHE means Very High Extent; HE means High Extent; LE means Low Extent while VLE means Very Low Extent

indicated that economic recession-induced problems have reduced the respective capacities of average citizens to pay for house rents; which has in turn also reduced the capacity and/or of landlords to effect repairs in the homes should the need arise. Additionally we find that the borrowing capacity of average citizens to pay for house rent or for maintaining owned houses was affected to a high extent, as indicated by items 6, 7 and 8 . The cluster means however seem to indicate that the economic recession-induced problems affected the capacity of the citizens in provision of shelter for family members more in rural areas than the urban areas. The standard deviation from the mean ranged from 0.51 - 1.01, again indicating that the respondents were close in their responses.

A corresponding hypothesis formulated to further address the research question is:

\section{Hypothesis Two}

Global Economic recession does not differ significantly in its effect between urban and rural areas on the capacity of the citizens in provision of shelter for family members in Enugu State of Nigeria.

The results presented in Table 4 indicate that global economic recession differs significantly between urban and rural areas on the capacity of the citizens in provision of shelter for family members in Nigeria. The overall calculated t-value of 7.309 has a probability value of .000 and therefore significant at .05 level of significance. The calculated t-values of 5.78,6.168 and 2.862 in respect of items 6,7 and 8 have probability values of $.000,000$ and .000 and therefore significant at .05 level of significance. Since the calculated t-values of the three items have probability values of less than .05 , the null hypothesis is rejected. Consequently, we find that economic recessioninduced problems impact more on rural area citizens than urban areas with regards to the capacity of the citizens to provide shelter for family members in Nigeria.

\section{Research Question Three}

To what extent does an economic recession influence the pattern to which the citizens take care of their health needs across urban and rural areas in Nigeria?

Data presented in Table 5 shows the mean ratings and standard deviations of respondents on extent global economic recession-induced problems influenced the pattern to which the citizens sought health care across urban and rural areas in Nigeria. The results indicate that the women from both urban and rural areas believe that economic recession-induced problems have reduced their capacity to seek medical care when sick; made it difficult for pregnant women, mostly in the rural areas to deliver in hospitals, thereby resulting in observed increases in maternal and infant mortality; caused more suicide, violent crimes, depression and hypertension as well as caused rise in mental health disorders to a high extent as indicated by items 9, 10,11 and 12. The cluster means also seem to show that economic recession-induced problems influenced the pattern to which the citizens take care of their health more in the rural than urban areas. The standard deviation from the mean ranged from $0.90-1.26$, indicating that the respondents were close in their responses

A corresponding hypothesis formulated to further address the research question is:-

\section{Hypothesis Three}

The effect of economic recession induced problems on the health seeking behavior of individuals does not differ significantly between urban and rural areas.

The results presented in Table 6 indicate that the effect of global economic recession-induced on health seeking 
Issues Bus. Manag. Econ.

Table 4. Results of t-test Analysis for Equality of Means of Respondents on Extent Economic Recession-Induced Problems affected the Capacity of the Citizens in Provision of Shelter for Family Members in Urban and Rural Areas in Nigeria

\begin{tabular}{|c|c|c|c|c|c|c|}
\hline & & \multicolumn{5}{|c|}{ t-test for Equality of Means } \\
\hline & & $\mathbf{T}$ & df & $\begin{array}{c}\text { Sig. } \\
\text { (2-tailed) }\end{array}$ & $\begin{array}{c}\text { Mean } \\
\text { Difference }\end{array}$ & Rmk \\
\hline \multirow[t]{2}{*}{ Item 6} & $\begin{array}{l}\text { Equal variances } \\
\text { Assumed } \\
\text { Equal variances }\end{array}$ & 5.178 & 431 & .000 & .44688 & $\mathbf{S}$ \\
\hline & Not Assumed & 6.059 & 164.7 & .000 & .44688 & \\
\hline \multirow[t]{2}{*}{ Item 7} & $\begin{array}{l}\text { Equal variances } \\
\text { Assumed } \\
\text { Equal variances }\end{array}$ & 6.168 & 431 & .000 & .72309 & $\mathbf{S}$ \\
\hline & Not Assumed & 8.760 & 254.4 & .000 & .72309 & \\
\hline \multirow[t]{2}{*}{ Item 8} & $\begin{array}{l}\text { Equal variances } \\
\text { Assumed } \\
\text { Equal variances }\end{array}$ & 2.863 & 431 & .004 & .32976 & $\mathbf{S}$ \\
\hline & Not Assumed & 3.227 & 154.4 & .002 & .32976 & \\
\hline \multirow[t]{2}{*}{ CLUSTER } & $\begin{array}{c}\text { Equal variances } \\
\text { Assumed Equal variances }\end{array}$ & 7.309 & 431 & .000 & .04509 & $\mathbf{S}$ \\
\hline & Not Assumed & 9.676 & 213.0 & .000 & .03406 & \\
\hline
\end{tabular}

Source: Field work data, 2020

Table 5: Mean scores and Standard Deviations of Respondents on Extent Economic Recession-Induced Problems have Influenced the Pattern to Which the Citizens Take Care of Their Health across Urban and Rural Areas in Nigeria

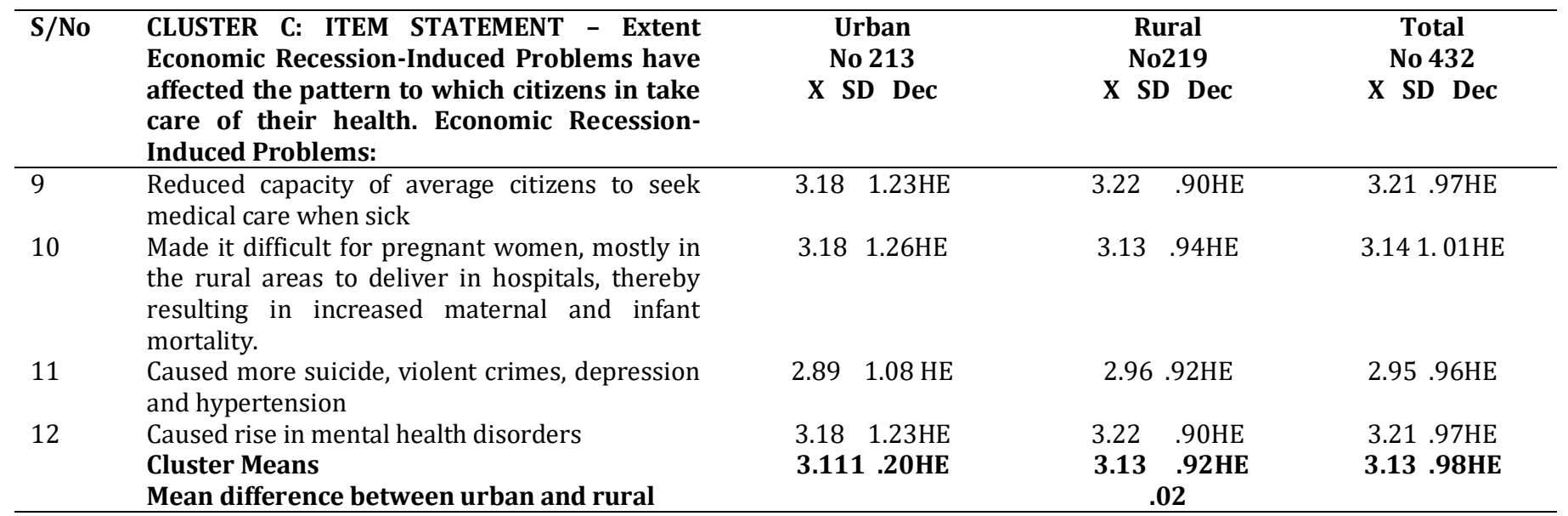

Source: Field work data, 2020

Key: VHE means Very High Extent; HE means High Extent; LE means Low Extent while VLE means Very Low Extent

behavior differed significantly between urban and rural areas. The overall calculated $\mathrm{t}$-value of 6.117 has a probability value of .000 and is therefore significant at a 0.05 level of significance. The calculated $t$-values of 3.214 , $4.854,3.867$ and 3.214 in respect of items $9,10,11$ and 12 have probability values of $.001,000, .000$ and .001 ; and are therefore also significant at .05 level of significance. Since the calculated $t$-values of the four items have probability values of less than .05, the null hypothesis of no significant difference in the influence of economic recession-induced problems on the health seeking behavior of citizens across urban and rural areas in Nigeria is rejected. We find that economic recession-induced problems impact more on rural area citizens than those in urban areas.

\section{Model Framework for the Quantitative Aspects}

$$
\begin{aligned}
& \log \left(\text { Health }_{t}\right)=\beta_{0}+\beta_{1} \log \left(\text { INFR }_{t}\right)+\beta_{2} \log \left(\text { INTR }_{t}\right)+ \\
& \beta_{3} \log \left(\mathrm{PDEBT}_{\mathrm{t}}\right)+\beta_{4} \log \left(\mathrm{POV}_{\mathrm{t}}\right)+\beta_{5} \log \left(\mathrm{REXR}_{\mathrm{t}}\right)+ \\
& \beta_{6} \log \left(\mathrm{UNER}_{\mathrm{t}}\right)+\varepsilon \\
& \text { Where, } \\
& \text { Health = Government expenditure on health } \\
& \text { INFR = Inflation rate } \\
& \text { INTR = Interest rate } \\
& \text { PDEBT = Public debt } \\
& \text { POV = Poverty rate } \\
& \text { REXR = Real exchange rate } \\
& \text { UNER = Unemployment rate } \\
& \beta_{0}=\text { Constant }
\end{aligned}
$$


Table 6. Results of t-test Analysis for Equality of Respondents on Extent Economic Recession-Induced Problems Influenced the Pattern of health seeking behavior

\begin{tabular}{|c|c|c|c|c|c|c|}
\hline & & \multicolumn{5}{|c|}{ t-test for Equality of Means } \\
\hline & & $\mathbf{t}$ & Df & $\begin{array}{c}\text { Sig. } \\
\text { (2-tailed) }\end{array}$ & $\begin{array}{c}\text { Mean } \\
\text { Difference }\end{array}$ & Rmk \\
\hline \multirow[t]{3}{*}{ Item 9} & Equal variances & 3.214 & 431 & .001 & .58437 & $\mathbf{S}$ \\
\hline & Assumed Equal variances & & & & & \\
\hline & Not Assumed & 4.844 & 299.0 & .000 & .58437 & \\
\hline \multirow[t]{4}{*}{ Item 10} & Equal variances & 4.854 & 431 & .000 & -.13380 & $S$ \\
\hline & Assumed & & & & & \\
\hline & Equal variances & & & & & \\
\hline & Not Assumed & 7.231 & 289.6 & .000 & -.13380 & \\
\hline \multirow[t]{4}{*}{ Item 11} & Equal variances & 3.867 & 431 & .000 & .51624 & $S$ \\
\hline & Assumed & & & & & \\
\hline & Equal variances & & & & & \\
\hline & Not Assumed & 4.635 & 172.3 & .000 & .51624 & \\
\hline \multirow[t]{3}{*}{ Item 12} & Equal variances & 3.214 & 431 & .001 & .58437 & $\mathbf{S}$ \\
\hline & Assumed Equal variances & & & & & \\
\hline & Not Assumed & 4.844 & 299.0 & .000 & .58437 & \\
\hline \multirow[t]{4}{*}{ CLUSTER } & Equal variances & 6.117 & 431 & .000 & .75803 & $\mathbf{S}$ \\
\hline & Assumed & & & & & \\
\hline & Equal variances & & & & & \\
\hline & Not Assumed & 8.417 & 234.2 & .000 & .75803 & \\
\hline
\end{tabular}

Source: Field work data, 2020

Table 7. Unit root test results

\begin{tabular}{lccc}
\hline Variable & \multicolumn{1}{c}{ Level } & First difference & Order of integration \\
\hline Log(Health) & $-1.326817\{0.6048\}$ & $-9.265101\{0.0000\}^{* * *}$ & $\mathrm{I}(1)$ \\
$\log (\mathrm{INFR})$ & $-2.955790\{0.0501\}$ & $-5.720308\{0.0000\}^{* * *}$ & $\mathrm{I}(1)$ \\
$\log (\mathrm{INTR})$ & $-4.356888\{0.0017\}^{* * *}$ & -- & $\mathrm{I}(0)$ \\
$\log (\mathrm{PDEBT})$ & $-2.094311\{0.2481\}$ & $-4.067005\{0.0036\}^{* * *}$ & $\mathrm{I}(1)$ \\
$\log (\mathrm{POV})$ & $-3.397128\{0.0205\}^{* *}$ & -- & $\mathrm{I}(0)$ \\
$\log (\mathrm{REXR})$ & $-3.567280\{0.0123)^{* *}$ & -- & $\mathrm{I}(0)$ \\
$\log (\mathrm{UNER})$ & $-1.322436\{6069\}$ & $-6.446585\{0.0000\}^{* * *}$ & $\mathrm{I}(1)$ \\
\hline
\end{tabular}

Note: ** and ${ }^{* * *}$ denote significance @ $5 \%$ and $1 \%$ respectively

Figures in parenthesis \{\} denote the $p$-values

\section{$\beta_{1}-\beta_{6}=$ Coefficients}

$\varepsilon=$ Error term

For the quantitative analysis, the Ordinary Least Squares (OLS) based Autoregressive Distributed Lag (ARDL) / Bounds testing approach was employed for testing the long-run co-integrating relationship among the time series variables. The Bounds testing methodology proposed by Pesaran \& Shin (1999) has some advantage over the conventional Johansen co-integration testing approach because it can be used with a mixture of I(0) and I(1) data. Generically, the "unrestricted" error correction model (ECM) of Pesaran \& Shin is given as shown in equation (2):

$$
\Delta \operatorname{In} Y_{t}=\propto_{0 y}+\sum_{i=1}^{n} \propto_{y i} \Delta Y_{t-1}+\sum_{i=1}^{n} \propto_{y i} \Delta X_{i t-1}+
$$

$\beta_{1 y} \operatorname{In} Y_{i t-1}+\beta_{2 y} \operatorname{In} X_{i t-1}+e_{i t} \ldots \ldots .$. Eqn. (2)

Where $\Delta$ is the first difference operator, $\alpha$ is the short-run dynamic coefficients of the model, and $\beta$ are the long-run effects.

As a preliminary step in ARDL/Bound testing, Augmented
Dickey Fully unit root test was used to confirm the order of integration of the time series variables. This is necessary because the presence of an order of integration higher than I(1) such as I(2) will invalidate the use of ARDL bounds test's computed F-statistic which is based on the assumption that the underlying variables must be either I(0) or I(1) or mutually integrated.

\section{Unit Root Test}

Unit root test was carried out to establish the order of integration. The results of the Augmented Dickey-Fuller based unit root test are as summarized in Table 7 .

Based on the results of the Augmented Dickey-Fuller unit root test in Table 8, all the variables are integrated of order I(1) except $\log ($ INTR), $\log (\mathrm{POV})$ and $\log (\mathrm{REXR})$ which are integrated of order $\mathrm{I}(0)$. Being that the variables are of mixed integration, that is, I(0) and I(1), the bounds testing/autoregressive distribution lag (ARDL) approach to 
Table 8: ARDL bounds test for co-integration

\begin{tabular}{lcc}
\hline Test Statistic & Value & K \\
\hline F-statistic & 13.52285 & 6 \\
Critical Value Bounds & & \\
Significance & I0 Bound & I1 Bound \\
$10 \%$ & 2.12 & 3.23 \\
$5 \%$ & 2.45 & 3.61 \\
$2.5 \%$ & 2.75 & 3.99 \\
$1 \%$ & 3.15 & 4.43 \\
\hline
\end{tabular}

Source: Researchers' E Views 9.0 Computation

Table 9. Summary of ARDL Model

\begin{tabular}{lllll}
\hline Variable & Coefficient & Std. Error & t-Statistic & Prob.* \\
\hline LOG(HEALTH(-1)) & -0.313195 & 0.162697 & -1.925019 & 0.0956 \\
LOG(HEALTH(-2)) & -0.289760 & 0.149896 & -1.933081 & 0.0945 \\
LOG(HEALTH(-3)) & -0.610165 & 0.143116 & -4.263435 & 0.0037 \\
LOG(INFR) & -0.600221 & 0.196012 & -3.062167 & 0.0183 \\
LOG(INFR(-1)) & 0.211943 & 0.183179 & 1.157027 & 0.2852 \\
LOG(INFR(-2)) & -0.222845 & 0.163921 & -1.359463 & 0.2162 \\
LOG(INTR) & -2.842273 & 0.476821 & -5.960883 & 0.0006 \\
LOG(INTR(-1)) & -1.110160 & 0.739958 & -1.500301 & 0.1772 \\
LOG(INTR(-2)) & -2.870611 & 0.680290 & -4.219684 & 0.0039 \\
LOG(PDEBT) & 1.442173 & 0.272469 & 5.292989 & 0.0011 \\
LOG(PDEBT(-1)) & 0.274512 & 0.382208 & 0.718225 & 0.4959 \\
LOG(PDEBT(-2)) & -0.729379 & 0.334524 & -2.180347 & 0.0656 \\
LOG(POV) & -0.271629 & 0.668437 & -0.406364 & 0.6966 \\
LOG(POV(-1)) & 3.108397 & 0.974346 & 3.190239 & 0.0153 \\
LOG(REXR) & 1.067308 & 0.185547 & 5.752227 & 0.0007 \\
LOG(REXR(-1)) & 0.476571 & 0.174271 & 2.734657 & 0.0291 \\
LOG(UNER) & -0.723599 & 0.276980 & -2.612460 & 0.0348 \\
LOG(UNER(-1)) & 0.314376 & 0.200880 & 1.564995 & 0.1616 \\
C & -0.262356 & 6.830544 & -0.038409 & 0.9704 \\
R-squared & & & & \\
Adjusted R-squared & 0.996672 & Mean dependent var & 3.181456 \\
S.E. of regression & 0.988115 & S.D. dependent var & 2.005299 \\
Sum squared resid & 0.218611 & Akaike info criterion & -0.053698 \\
Log likelihood & 0.334534 & Schwarz criterion & 0.865681 \\
F-statistic & 19.69807 & Durbin-Watson stat & 0.211050 \\
Prob(F-statistic) & 116.4758 & & & 1.934644 \\
\hline
\end{tabular}

Source: Researchers' E Views 9.0 Computation

ordinary least squares (OLS) was used for the empirical analysis.

\section{Lag Selection Criteria}

The outcome of the lag selection criteria is as shown in appendix III.

The study used the optimal lag length suggested by the Hannan Quinn criteria for the variables used in the model $(3,2,2,2,1,1$ and 1$)$. The next necessary test is the cointegration test for possible long-run relationship between the variables.

\section{Bounds Testing Approach to Co-integration}

The bounds testing yielded the following results:

The calculated F-statistic (13.52285) of the bounds testing is greater than the critical value of the upper and lower bounds at $5 \%$ and $1 \%$ critical values. This implies that collectively, the explanatory variables have a long-run relationship with the dependent variable. 
Table 10. Estimated long-run coefficients

\begin{tabular}{|c|c|c|c|c|}
\hline \multicolumn{5}{|l|}{ Co-integrating Form } \\
\hline Variable & Coefficient & Std. Error & t-Statistic & Prob. \\
\hline DLOG(HEALTH(-1)) & -0.320405 & 0.227797 & -1.406538 & 0.2024 \\
\hline DLOG(HEALTH(-2)) & -0.610165 & 0.143116 & -4.263435 & 0.0037 \\
\hline DLOG(INFR) & -0.600221 & 0.196012 & -3.062167 & 0.0183 \\
\hline DLOG(INFR(-1)) & 0.222845 & 0.163921 & 1.359463 & 0.2162 \\
\hline DLOG(INTR) & -2.842273 & 0.476821 & -5.960883 & 0.0006 \\
\hline DLOG(INTR(-1)) & 2.870611 & 0.680290 & 4.219684 & 0.0039 \\
\hline DLOG(PDEBT) & 1.442173 & 0.272469 & 5.292989 & 0.0011 \\
\hline DLOG(PDEBT $(-1))$ & 0.729379 & 0.334524 & 2.180347 & 0.0656 \\
\hline DLOG(POV) & -0.271629 & 0.668437 & -0.406364 & 0.6966 \\
\hline DLOG(REXR) & 1.067308 & 0.185547 & 5.752227 & 0.0007 \\
\hline DLOG(UNER) & -0.723599 & 0.276980 & -2.612460 & 0.0348 \\
\hline $\operatorname{ECT}(-1)$ & -0.992790 & 0.271412 & -3.657872 & 0.0081 \\
\hline \multicolumn{5}{|c|}{$\begin{array}{l}\text { Cointeq }=\text { LOG(HEALTH) }-(-0.6156 * \text { LOG(INFR) }-6.8726 * \text { LOG(INTR })+ \\
0.9945 * \text { LOG(PDEBT })+2.8574 * \text { LOG(POV) + 1.5551*LOG(REXR) }-0.4122\end{array}$} \\
\hline
\end{tabular}

\section{Long Run Coefficients}

\begin{tabular}{lcccc} 
Variable & Coefficient & Std. Error & t-Statistic & Prob. \\
\hline LOG(INFR) & -0.615561 & 0.308504 & -1.995312 & 0.0862 \\
LOG(INTR) & -6.872594 & 0.891746 & -7.706898 & 0.0001 \\
LOG(PDEBT) & 0.994476 & 0.118941 & 8.361109 & 0.0001 \\
LOG(POV) & 2.857370 & 1.723054 & 1.658317 & 0.1412 \\
LOG(REXR) & 1.555091 & 0.410837 & 3.785179 & 0.0068 \\
LOG(UNER) & -0.412195 & 0.424099 & -0.971931 & 0.3635 \\
C & -0.264261 & 6.926255 & -0.038154 & 0.9706 \\
\hline
\end{tabular}

Source: Researchers' E Views 9.0 computation

\section{Estimated Coefficients of the ARDL Model}

The ARDL model produced the following results in Table 9 below:

From the above results, the R-squared indicates that the explanatory variables accounted for approximately $99 \%$ of the total variations in the dependent variable, while the Fstatistics confirms that the joint effect of the explanatory variables was significant. The coefficient of three periods lag of $\log$ (HEALTH) indicates that health expenditure of the past three years contributed significantly to current years' health expenditure.

Furthermore, the estimated coefficients for the short and long-run effects are as shown in Table 10 below:

The coefficient of the error correction term (ECT) rightly entered with a negative sign and is statistically significant. This aligns with the results of the F-statistic derived from the ARDL bounds test of co-integration. This indicates that the extent to which the deviation from the long-run equilibrium is corrected through partial short-run adjustments. As well, the ECT of -0.992790 indicates that approximately $99 \%$ of last years' deviation was corrected in the current year. On the other hand, the short coefficient shows that inflation rate, interest rate, public debt and unemployment rate are significant determinants of health expenditure, while poverty rate was insignificant.

The results indicate that the long-run coefficient estimate of inflation rate (INFR) is -0.615561 . This implies that a $1 \%$ increase in inflation rate accounted for about $61 \%$ decrease in health expenditure. A plausible reason for the inverse relationship between inflation rate and health expenditure could be due to the fact that government would always cut her expenditures in a bid to reduce inflation. Hence, in a period of high inflation rate, health expenditure (among other government expenditures) is bound to decrease as government seeks to control the rate of inflation. However, the p-value (0.0862) is slightly greater than the 5\% level of significance which suggests that the effect of inflation on health expenditure is not significant in the long run.

Based on the estimated coefficient of interest rate (INTR), it reveals that health expenditure changed negatively as a result of $1 \%$ increase in interest rate. The coefficient suggests that $1 \%$ increase in interest rate results to about $6.87 \%$ decrease in health expenditure. This could be due to the fact that a rise in interest rate causes inflationary pressure on the economy. For instance, a rise in lending 
Table 11. Diagnostic test for the ARDL model

\begin{tabular}{lcc}
\hline Test & Statistic & Prob. \\
\hline Jarque-Bera normality test & 0.261011 & 0.877652 \\
Heteroskedasticity & 1.026758 & 0.5210 \\
Breuch-Godfrey serial correlation & 0.5624 & 0.0690 \\
\hline
\end{tabular}

Source: Researchers' E Views 9.0 Computation

rate could result in high cost of borrowing; hence increase in aggregate price level as investors seek to recover interests paid on loans by increasing the prices of their products. This supports the notion that interest exerts pressure on expenditure through its multiplier effect on inflation rate. The $p$-value $(0.001)$ indicates that the effect of interest rate on health expenditure is significant.

The coefficient of public debt (PDEBT) is 0.994476 and implies that a $1 \%$ increase in public debt accounts for approximately $99 \%$ increase in health expenditure in the long-run. This is so because government usually borrows to cover revenue shortfalls in Nigeria. Hence, when the government borrows, funds will be available for public expenditure (with health expenditure inclusive). With a pvalue (0.0001), it was found that public debt has a significant effect on health expenditure in the long-run.

With an estimated coefficient of 2.857370 , it was found that $1 \%$ increase in poverty rate accounts for positive changes in health expenditure in the long-run. This reflects the fact that government is usually propelled to expend resources on key economic sectors to curb poverty. As such, in times of high poverty rate, government expenditure is expected to increase. For instance, due to the high incidence of poverty in rural areas in Nigeria, government expends resources for healthcare services to make life easier for these rural dwellers. However, the p-value (0.1412) that corresponds to the coefficient of poverty rate is greater than 0.05 , therefore the effect of poverty rate on health expenditure is not significant. However, the p-value (0.1412) corresponds to a coefficient of poverty rate that is greater than 0.05 . Thus we find that the effect of poverty rate on health expenditure is not significant.

Another finding relates to the coefficient estimate of real exchange rate (REXR) which reveals that $1 \%$ increase in real exchange rate caused health expenditure to increase by 1.555091. This implies that health expenditure complies positively to increase in real exchange rate. This is in line with the notion that depreciation in exchange rate facilitates export trade, and Nigeria being a country dependent on revenue from crude oil exports is able to generate foreign exchange revenue amidst exchange rate depreciation in the long-run. This relationship is significant following the p-value (0.0068) which is less than 0.05.

The long-run coefficient of unemployment rate is 0.412195 . This indicates that a percentage increase in unemployment results to about $41 \%$ decrease in health expenditure in the long-run. This could be due to the fact that unemployment reduces the labour force thereby reducing the tax revenue from personal income. Hence, with a possible decrease in tax revenue occasioned by increased unemployment, government revenue drops and health expenditure is decreased. However, the p-value suggests that unemployment rate is not a significant determinant of health expenditure in Nigeria.

\section{Diagnostic Tests}

Table 11 provides the diagnostic test results for the ARDL estimation:

As observed from table 5, the ARDL model passed all the diagnostic tests of serial correlation, heteroskedasticity test and normality test suggesting that the ARDL model is well specified.

\section{DISCUSSION OF RESULTS}

1. Global economic recession affected the regularity of feeding habit in rural areas to a very high extent while it affected the regularity of feeding habit in urban areas only to a high extent. Regular feeding of three square meals per day for average citizens to a high extent was difficult for urban respondents while the severity for the rural respondents was to a very high extent. This result is in agreement with the findings of Massaavrat and Sha (2015).

2. Global economic recession affected the capacity of the citizens in providing for shelters to family members more in rural areas than in urban areas to the extent that it reduced the ability of an average tenant to pay house rent. Again we found that the severity for urban dwellers was to a high extent and reduced the income of landlords from rented homes to a high extent. This result is in consonance with the results of Oyesiku (2019).

3. Generally, the global economic recession reduced the extent to which average citizens both in urban and rural areas take care of their health when sick and increased violence, crime, depression and hypertension to high extents. Muanya (2016) supported this result.

4. Findings of regression analysis reveal that both public debt and real exchange rate have positive and significant effects on health expenditure in both the short and long-run. The effect of inflation on health expenditure was negative but more significant in short-run than in longrun. However, effect of interest rate on health expenditure was negative and significant in both long-run and shortrun. Aggregative poverty reduced health expenditure in the 
short run but increased it in the long-run though these effects were insignificant.

\section{Conclusion}

In conclusion, the indicators of economic recession considered in the study jointly affected health expenditure in the long-run as shown by the F-statistic of the ARDL (bounds test inclusive). This research concludes that the most significant indicators of global economic recession in Nigeria are interest rate, public debt and real exchange rate since they were significant in both the long-run and shortrun. This may be due to external borrowings. Hence, the study concludes that the effect of economic recession on health is significant over the period of study.

\section{Conflict of Interests}

The authors declare that there is no conflict of interests regarding the publication of the paper.

\section{REFERENCES}

Afolabi E, Comfort Y, (2019). The Invisibility of Women's Organizations in Decision Making Process and Governance in Nigeria. Retrieved online from 2(3): 23-41.

Ali A (2006). Fundamental of Research in Education. Awka, Nigeria. Meks Publishers.

Buar A (2009). The Social Impacts of the Global Financial Crisis on the Poor and Vulnerable People in Asia. Paper Presented during the Policy Forum on Labour Market Policy. 1(6): 79-81.

Burgard SA, Hawkins JM (2014). Race/Ethnicity Educational Attainment, and Foregone Health Care in the United States in the 2007-2009 Recession American J. Public Health 2(104): 134-140.

Chen J, Dagher R (2014). Gender and Race/Ethnicity Differences in Mental Health Care Use before and During the Great Recession. J. Behavioural Health Services Res. 4(8): 1-12.

Cheung E, Sandra A, Marriot T, Brian U, (2015). Impact of an Economic Downturn and Addiction and Mental Health Service Utilization: A review of the Literature 1(3): 89-98.

Chinguwo P, Blewita J, (2012). The Global Financial Crisis, Working People and Sustainable Development. A Schumacher Institute paper 3(11): 235-243.

Frasquilho I, Diana R, Margarida O, Gaspar M, Salonna E, Ferdinand R, Diogo Y, Guerreiro I, Storti E, Claudia C, Gaspar T, Tonia H, Caldas-de-Almeida, JM, (2016). Mental Health Outcomes in Times of Economic Recession: A systematic literature Review Published by Biomed Central Public Health, 3(6): 34-42.

Gautan E, Omviri U, Singh VR, Sharma R, (2015). Global Recession and its Impact on Telecommunication Industry: An Empirical Dissertation International J. Manag. Bus. 5(2): 107-116.
JCDA. (Journal of Canadian Dentist's Association) (2009). www.cda-adc.ca/jcda.May2000 Vol. 75 N. 4/267 pdf. 1(13): 132-140.

Kelly J (2011). The Eight stage Maslow's Hierarchy of Needs Published by the Peak Performance Centre, Journal of Economics and Social Science, 4(2): 13-23.

Krugman P (1998). Are Recessions the Inevitable Payback for good Times? Mises Review 5(1): 1-15.

Mailafia DI (2016). The Structural Economic Dimensions of Unemployment. Associated Factors and Imperatives for Sustainable Development in Nigeria. Being an Inaugural Lecture, University of Jos.

Masarrate G, Suchita JH, (2015). Assessing the Impact of Recession on Consumers Behaviour: An Empirical Study in Dubai Researchers World, 6(2): 21-33. July www./questa.com.

Maslow A (1943). A Theory of Human Motivation in Psychological Review. Wikipedia.org.

Muanya C, Chukwu F, (2017). Tackling Economic Recession - Induced Mental Health Disorder. Guardian Newspaper of 16 August.

Olugbile F (2016). Cited in Muanya, (2017). Tackling Health Disorders. Guardians Newspapers, 16 August.

Opejobi S. (2017). Why Dr. Orji Jumped into Lagos Lagoon. Colleagues Reveals. Daily post Daily post.ng/2017/03/21, Reported by Essien Attah at $3^{\text {rd }}$ Mainland Bridge Lagos.

Oyesiku K (2009). "Economic Meltdown:The Implication for Sustainable Development in Nigeria". The Nigerian Accountant 42(3): 33-41.

Oyesiku K (2009). "Global Economic Recession and Management of Change, 2009 Anniversary Dinnerand Investure of New Chairman of the Charttered Institute of Taxation of Nigeria. Abeokuta DistrictSociety, Public Guest Lectuer Delivered on Tuesday 5 ${ }^{\text {th }}$ March, 2009 at the Internal Revenue Service.

Tejvan P (2011). Problems of Economic Recession. Economics Help org. Oct 11 Complex, Abeokuta. The Wall Street Journal (2009), 2(3): 1-12.

Ugwuanyi GO, Obiekwe J, Chinelo O (2017). Impact of Economic Recession Induced Problems on Nigerian Economic Growth. J. Emerging Issues in Economics, Finance and Banking Dubai, 3(4): 43-51.

Wikipedia, the free Encyclopedia (2017). Global Recession Retrieved on 24/05/17.

World Data Atlas (2011-2018). Nigeria Total Health Expenditure as a share of GDP. 


\section{APPENDIX 1}

\section{RAW DATA}

\begin{tabular}{|l|l|l|l|l|l|l|l|}
\hline YEAR & HEALTH EXP. & REXR & INTR & INFR & POV & UNER & PDEBT \\
\hline 1985 & 0.13 & 490.41 & 9.25 & 4.67 & 53.3 & 6.10 & 40.48 \\
\hline 1986 & 0.13 & 266.9 & 10.50 & 5.39 & & 5.30 & 45.25 \\
\hline 1987 & 0.04 & 85.17 & 17.50 & 10.18 & & 7.00 & 69.89 \\
\hline 1988 & 0.42 & 85.57 & 16.50 & 56.04 & & 5.30 & 137.57 \\
\hline 1989 & 0.58 & 76.18 & 26.80 & 50.47 & & 4.50 & 180.98 \\
\hline 1990 & 0.50 & 70.8 & 25.50 & 7.5 & 49.1 & 3.50 & 287.44 \\
\hline 1991 & 0.62 & 59.95 & 20.01 & 12.7 & 50.8 & 3.10 & 382.71 \\
\hline 1992 & 0.15 & 49.73 & 29.80 & 44.81 & 57.1 & 3.40 & 444.65 \\
\hline 1993 & 3.87 & 54.5 & 18.32 & 57.17 & 56.9 & 2.70 & 722.22 \\
\hline 1994 & 2.09 & 100.81 & 21.00 & 57.03 & 60 & 2.00 & 906.98 \\
\hline 1995 & 3.32 & 160.13 & 20.18 & 72.81 & 62.4 & 1.80 & 1056.39 \\
\hline 1996 & 3.02 & 19.07 & 19.74 & 29.29 & 65.6 & 3.40 & 1194.59 \\
\hline 1997 & 3.89 & 19.22 & 13.54 & 10.67 & 67.3 & 3.20 & 1037.29 \\
\hline 1998 & 4.74 & 19.88 & 18.29 & 7.86 & 61.1 & 3.20 & 1097.68 \\
\hline 1999 & 16.64 & 53.76 & 21.32 & 6.62 & 61.5 & 3.00 & 1193.84 \\
\hline 2000 & 15.22 & 58.25 & 17.98 & 6.94 & 62.8 & 18.10 & 3372.18 \\
\hline 2001 & 24.52 & 70.58 & 18.29 & 18.87 & 60.7 & 13.70 & 3995.63 \\
\hline 2002 & 40.62 & 85.13 & 24.85 & 12.89 & 63.4 & 12.20 & 4193.27 \\
\hline 2003 & 33.27 & 106.68 & 20.71 & 14.03 & 53.5 & 14.80 & 5098.89 \\
\hline 2004 & 34.20 & 126.69 & 19.18 & 15.01 & 54.4 & 11.80 & 6260.59 \\
\hline 2005 & 55.66 & 143.78 & 17.95 & 17.85 & 66.4 & 11.90 & 4220.97 \\
\hline 2006 & 62.25 & 148.33 & 17.26 & 8.24 & 61.2 & 12.30 & 2204.72 \\
\hline 2007 & 81.91 & 155.75 & 16.94 & 5.38 & 55.7 & 12.70 & 2608.52 \\
\hline 2008 & 98.22 & 90.31 & 15.14 & 11.6 & 58.4 & 14.90 & 2843.56 \\
\hline 2009 & 90.20 & 97.44 & 18.99 & 12.5 & 53.5 & 19.70 & 3818.46 \\
\hline 2010 & 99.10 & 93.39 & 17.59 & 13.7 & 69 & 21.10 & 5241.65 \\
\hline 2011 & 231.80 & 89.82 & 16.02 & 10.8 & 71 & 23.90 & 6519.69 \\
\hline 2012 & 197.90 & 79.58 & 16.79 & 12 & 67.5 & 25.40 & 7564.44 \\
\hline 2013 & 179.99 & 74.20 & 16.72 & 8.5 & 60 & 23.50 & 8492.55 \\
\hline 2014 & 195.98 & 69.51 & 16.55 & 8 & 49.4 & 24.30 & 9535.54 \\
\hline 2015 & 257.72 & 70.83 & 16.85 & 9 & 53.3 & 9.00 & 10948.53 \\
\hline 2016 & 202.36 & 80.36 & 16.87 & 15.7 & 59.2 & 13.40 & 14573.12 \\
\hline 2017 & 236.10 & 85.62 & 17.78 & 15.4 & & 16.50 & 18366.31 \\
\hline & & & & & & &
\end{tabular}

\section{APPENDIX II}

\section{QUESTIONNAIRE}

\section{INSTRUMENT}

\section{Section A - Personal Data}

Please tick $(\sqrt{ })$ the appropriate response as applicable
1. State:
2. Name of women Organization
3. Location: Urban

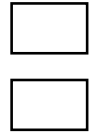
Enugu
Section B: Questionnaire
Rural
Key:
$=$ Very Great Extent
VGE
$=$ Great Extent
GE
= Low Extent
VLE
= Very Low Extent 


\begin{tabular}{|c|c|c|c|c|c|}
\hline $\mathbf{S} / \mathbf{N}$ & $\begin{array}{l}\text { CLUSTER A: ITEM STATEMENT - Extent Economic Recession-Induced } \\
\text { Problems have affected the regularity feeding. Economic Recession-Induced } \\
\text { Problems: }\end{array}$ & VGE & GE & LE & VLE \\
\hline 1 & Make things difficult for the average citizens to have three square meals per day. & & & & \\
\hline 2 & Make it difficult for the average citizens to eat balanced diet meals & & & & \\
\hline 3 & Have reduced an average citizen's market access to available resources & & & & \\
\hline 4 & Have reduced an average citizen's access to available resources & & & & \\
\hline \multirow[t]{2}{*}{5} & Have reduced capacity of average citizens to farm products. & & & & \\
\hline & $\begin{array}{l}\text { CLUSTER B: ITEM STATEMENT - Extent Economic Recession-Induced } \\
\text { Problems have affected the citizen in the provision of shelter for family } \\
\text { members. Economic Recession-Induced Problems: }\end{array}$ & & & & \\
\hline 6 & Have reduced capacity of average citizens to pay for house rents & & & & \\
\hline 7 & Have reduced capacity of landlords to effect repairs in their houses & & & & \\
\hline \multirow[t]{2}{*}{8} & $\begin{array}{l}\text { Have reduced the borrowing capacity of average citizens to pay for house rent or } \\
\text { for maintaining owned houses }\end{array}$ & & & & \\
\hline & $\begin{array}{l}\text { CLUSTER C: ITEM STATEMENT - Extent Economic Recession-Induced } \\
\text { Problems have affected the pattern to which citizens in take care of their } \\
\text { health. Economic Recession-Induced Problems: }\end{array}$ & & & & \\
\hline 9 & Have reduced capacity of average citizens to seek medical care when sick & & & & \\
\hline 10 & $\begin{array}{l}\text { Made it difficult for pregnant women, mostly in the rural areas to deliver in } \\
\text { hospitals, thereby resulting to child and mother's death during birth. }\end{array}$ & & & & \\
\hline 11 & Caused more suicide, violent crimes, depression and hypertension & & & & \\
\hline 12 & Caused rise in mental health disorders & & & & \\
\hline
\end{tabular}

